\title{
Influence of an increase in excise duty on alcohol consumption and its adverse effects
}

\author{
R E KENDELL, M DE ROUMANIE, E B RITSON
}

\begin{abstract}
The excise duty on alcoholic beverages was increased in March 1981, causing the cost of alcohol to rise faster than other prices for the first time in 30 years. For this reason 463 "regular drinkers" in the Lothian region whose drinking habits had been established in 1978-9 were reinterviewed in 1981-2. Overall, their alcohol consumption had fallen by $18 \%$ and associated adverse effects by $16 \%$. Heavy drinkers and suspected dependent drinkers both reduced their consumption at least as much as light or moderate drinkers and suffered considerably fewer adverse effects as a result. Increasing the excise duty on alcoholic beverages can therefore be an effective public health measure. Factors related to rising unemployment were responsible for about $20 \%$ of the overall reduction in consumption.
\end{abstract}

\section{Introduction}

There is good evidence that the many medical and social ill effects of alcohol increase in frequency when consumption per head rises and decrease when consumption falls. ${ }^{1-4}$ It is also well established that alcohol consumption usually rises when

\footnotetext{
Edinburgh University Department of Psychiatry, Royal Edinburgh Hospital, Edinburgh EH10 5HF

R E KENDELL, MD, FRCP, professor of psychiatry

$M$ DE ROUMANIE, MA, research associate

E B RITSON, MD, FRCPSYCH, consultant psychiatrist and part time senior lecturer

Correspondence to: Professor R E Kendell.
}

incomes rise or the price of alcoholic beverages falls and that consumption falls when prices rise. ${ }^{1-35}$ It has therefore been suggested that the most effective means of reducing the widespread ill effects of alcohol abuse might be to raise the real price of alcoholic beverages by an increase in taxation. Critics of this strategy maintain, however, that deliberately increasing the price of alcohol would be ineffective and socially undesirable, because it would influence the drinking habits of only normal social drinkers. Indeed this was argued by the Health Departments themselves in their recent discussion document Drinking Sensibly": "Increasing the real price of alcohol is not likely to influence many problem drinkers, who will probably maintain their consumption by switching to a cheaper drink or reducing their expenditure on other items-perhaps to the detriment of their family."

Although there is evidence that price rises do lead to a reduction in adverse effects as well as in consumption ${ }^{5} 8$ it has never been possible to establish which drinkers drink less when prices rise. This is because an appropriate prospective survey can be designed only if the date of a major price rise is known well beforehand, and increases in taxation never are announced in advance. By chance, however, we had an opportunity to carry out a prospective before and after comparison of this type.

\section{Methods}

In 1978-9 a random sample of 1007 residents of the Lothian region (Edinburgh and its hinterland) over the age of $17 \frac{1}{2}$ were surveyed as part of a comparison of drinking habits and attitudes to alcohol in Scotland, Mexico, and Zambia. ${ }^{9}$ Among other things all 1007 (608 men and 399 women) had been asked precisely what they had drunk in the previous seven days. In March 1981 the excise duty on alcoholic beverages was increased sharply, particularly on beer. The combination of that increase in taxation and price increases imposed by the 
brewers themselves meant that, for the first time in over 30 years, the price of alcoholic beverages increased faster than the retail price index. Arrangements were therefore quickly made to reinterview in the autumn of 1981 the 676 respondents (484 men and 192 women) who had had at least one alcoholic drink in the seven days on which the original survey had been based-the so-called "regular drinkers."

The first survey was carried out between July 1978 and February 1979 and the second between September 1981 and March 1982. The same agency (System Three Scotland Ltd) was used each time and no interviews were held over either of the Christmas/New Year holiday periods. Table I shows the main economic changes taking place between November 1978 and November 1981, the mid points of the two surveys.

TABLE I-Underlying economic changes

\begin{tabular}{|c|c|c|c|}
\hline & Nov 1978 & Nov 1981 & $\underset{\left({ }^{\circ} 0\right)}{\text { Change }}$ \\
\hline $\begin{array}{l}\text { Retail Price Index:* } \\
\text { All items } \\
\text { All alcoholic beverages } \\
\text { Beer } \\
\text { Spirits, wines }\end{array}$ & $\begin{array}{l}202 \cdot 2 \\
198 \cdot 4 \\
213 \cdot 4 \\
177 \cdot 8\end{array}$ & $\begin{array}{l}306 \cdot 9 \\
319 \cdot 3 \\
361 \cdot 3 \\
262 \cdot 8\end{array}$ & $\begin{array}{l}+52 \\
+61 \\
+69 \\
+48\end{array}$ \\
\hline $\begin{array}{l}\text { Personal disposable income }(£)^{\dagger} \\
\text { Average weekly earnings, all employees }(£): \ddagger\end{array}$ & $\begin{array}{l}1978 \\
1947 \\
85.9\end{array}$ & $\begin{array}{l}1981 \\
3014\end{array}$ & $\begin{array}{l}+55 \\
+61\end{array}$ \\
\hline $\begin{array}{l}\text { Men aged } 21 \text { and over } \\
\text { Women age } 18 \text { and over }\end{array}$ & $\begin{array}{l}85.9 \\
56.0\end{array}$ & $\begin{array}{r}138.1 \\
91.0\end{array}$ & $\begin{array}{l}+61 \\
+63\end{array}$ \\
\hline Unemployment in Edinburgh area $\left({ }^{0}{ }_{0}\right): \S$ & $\begin{array}{c}\text { fune } 1978 \\
7.9\end{array}$ & $\begin{array}{c}\text { fune } 1982 \\
14 \cdot 2\end{array}$ & \\
\hline $\begin{array}{l}\text { Men } \\
\text { Women }\end{array}$ & 4 & $7 \cdot 9$ & \\
\hline
\end{tabular}

*From Employment Gazette, January $1974=100$

†Figures for Scotland from Scottish Economic Bulletin.

+Figures for Lothian region from Scottish Economic Bulletin.

§̧From Manpower Services Commission.

Over those three years, the cost of alcoholic beverages rose by $61 \%$ while the retail price index rose by only $52 \%$. Average earnings in the Lothian region and average personal disposable income in Scotland both rose more than the retail price index, suggesting that those in regular employment were marginally better off in 1981. But unemployment in the Edinburgh "travel to work area" rose steeply between 1978 and 1982 for both men and women.

Of the original 676 regular drinkers, $463(69 \%)$ were successfully reinterviewed. Of the 213 who were not, 85 could not be traced, 48 were known to have left the region, 39 refused, and 23 were either dead or too ill to be interviewed. A disproportionate number of lost respondents were under the age of 30, unmarried, and not in regular employment. Nevertheless, the sex ratio and both male and female alcohol consumption at the time of the first survey of the 463 who were reinterviewed were representative of the original sample.

\section{Results}

Attention was focused on the difference in the total number of units of alcohol (one unit being half a pint of beer, one measure of spirits, or one glass of wine, each of which contains about $9 \mathrm{~g}$ of ethanol) consumed in the seven days before the first and the seven days before the second surveys. In calculating these $\mathrm{D}$ scores allowance was made for the fact that everyone was three years older at the second survey and that alcohol consumption tends to fall with increasing age. Overall, consumption fell from an average of 17.5 alcohol units a week in 1978-9 to an average of 14.4 units a week in 1981-2, a fall of 3.1 units a week $(18 \%$ ). Consumption of beer fell by $25 \%$ and of spirits by $20^{\circ}{ }_{0}^{\circ}$, while that of wine and sherry rose slightly.

The main purpose of the survey was to find out whether heavy drinkers reduced their consumption more or less than moderate drinkers, if indeed they cut down at all. Table II shows the changes reported. This striking relationship between level of consumption in 1978-9 and the reduction in consumption between then and the second survey (the D scores), with the heaviest drinkers reducing their consumption very greatly while the lightest drinkers actually increased their consumption, was largely the effect of "regression to the mean." The problem is that most people's drinking varies somewhat from week to week. Some of the men drinking only 1-10 units a week in 1978-9 would normally have drunk more than this, and some of those drinking over 51 units would normally have drunk less. So when in 1981-2 they were interviewed at the end of a more
TABLE II-Changes in alcohol consumption between the first and second surveys

\begin{tabular}{cccc}
\hline $\begin{array}{c}\text { Intake in } \\
1978-9\end{array}$ & No & $\begin{array}{c}\text { Mean intake in } \\
1978-9 \text { (units) }\end{array}$ & D score \\
\hline Men & 329 & $21 \cdot 7$ & $-3 \cdot 8\left(-18^{\circ}{ }^{\circ}\right)$ \\
$1-10$ units & 137 & $4 \cdot 8$ & $+3 \cdot 4\left(+72^{\circ}\right)$ \\
$11-30$ units & 117 & $18 \cdot 8$ & $+1 \cdot 1\left(+6^{\circ}{ }^{\circ}\right)$ \\
$31-50$ units & 41 & $39 \cdot 4$ & $-10 \cdot 9\left(-28^{\circ}{ }^{\circ}\right)$ \\
$>50$ units & 34 & $78 \cdot 6$ & $-41 \cdot 4\left(-53^{\circ}{ }^{\circ}\right)$ \\
Women & 134 & $2 \cdot 6$ & $-1 \cdot 4\left(-20^{\circ}\right)$ \\
$1-5$ units & 74 & $7 \cdot 9$ & $+0 \cdot 7\left(+28^{\circ}\right)$ \\
$6-10$ units & 31 & $17 \cdot 7$ & $-1 \cdot 7\left(-22^{\circ}{ }^{\circ}\right)$ \\
$>10$ units & 29 & & $-6.5\left(-37^{\circ}{ }^{\circ}\right)$ \\
& & & \\
\hline
\end{tabular}

typical week light drinkers appeared to be drinking more and heavy drinkers to be drinking less. We tried to calculate how much of these overali changes in consumption was due to genuine increases or decreases and how much simply to this regression effect in two ways: by plotting log consumption in 1978-9 against log consumption in 1981-2 after removing all respondents with zero consumption in 1981-2 (to compensate for the lack of data for those with zero consumption in 1978-9) and examining the symmetry of these scattergrams; and by regression analyses with log consumption in 1978-9 as the independent and log consumption in 1981-2 as the dependent variable. The results indicated that heavy drinkers did not depart significantly, in either direction, from the general tendency to drink less. After allowing for regression to the mean and the absence of any data in 1981-2 for people with zero consumption in 1978-9 the true D score of men drinking over 50 units in 1978-9 was estimated to be -11.4 units.

In the second survey everyone was asked whether they thought they were drinking more or less than they had been three years before. As table III shows, $47 \%$ thought they were drinking less and only $13 \%$ that they were drinking more and these opinions corresponded well with the changes in their recorded consumption between the two surveys. Of those who thought they were drinking less than

TABLE III-Opinions about changes in consumption in past three years

\begin{tabular}{lrcr}
\hline \multicolumn{1}{c}{ Opinion } & No $\left({ }_{0}\right)$ & $\begin{array}{c}\text { Change in } \\
\text { past year }\left(\text { No }\left({ }_{0}\right)\right.\end{array}$ & $\begin{array}{c}\text { Mean } \\
\text { D score }\end{array}$ \\
\hline Drinking more & $59(13)$ & $31(53)$ & +9.5 \\
Drinking less & $216(47)$ & $159(74)$ & -8.6 \\
No change & $186(40)$ & & -0.5
\end{tabular}

they had been three years earlier, $159(74 \%)$ said the change had taken place in the past year compared with only $31(53 \%)$ of those who thought their drinking had increased. The difference between these two percentages is statistically significant $(p<0.01)$ and is presumably related to the fact that the increase in excise dutv took place less than 12 months before the second survey. The 31 respondents who thought their drinking had increased in the past year offered a variety of explanations for this increase, of which increased earnings (13), joining a new group of heavy drinking friends (10), and problems, stress, or loneliness (9) were the commonest. The main explanation offered by the much larger number who said that their drinking had decreased in the past year was the increased price of alcohol (cited by 94 of the 159). Other commonly mentioned reasons were being older and more mature (53), increased financial commitments (45), a fall in income (44), and considerations of health (35).

Changes in drinking habits are important only if they are accompanied by corresponding changes in adverse effects. In both surveys all respondents were asked if they had experienced any of 14 ill effects-for instance, getting into a fight through drinking, being in a road accident after drinking-within the past year. It was therefore possible to produce a crude adverse effects score, for both 1978-9 and $1981-2$, by adding together all positive replies to these 14 questions. As table IV shows, the average adverse effects score of all 463 respondents was 0.88 in $1978-9$ and 0.74 in $1981-2$. The difference is statistically significant $(t=2.40$ and $\mathrm{p}<0.02)$ and constitutes a $16 \%$ reduction in adverse effects, very similar in magnitude to the $18 \%$ reduction in consumption. As one might expect, adverse effects were much commoner in heavy drinkers than in moderate drinkers. There was a fourfold difference in the average adverse effects scores of men drinking more than 50 units a week and those drinking less than this amount and a threefold difference in the average scores of 
TABLE IV-Adverse effects of drinking

\begin{tabular}{|c|c|c|c|c|}
\hline & \multicolumn{3}{|c|}{ Mean adverse effects score } & \multirow[b]{2}{*}{ Change } \\
\hline & No & $1978-9$ & $1981-2$ & \\
\hline $\begin{array}{l}\text { All respondents } \\
\text { Intake in } 1978-9 \text { : }\end{array}$ & 463 & 0.88 & 0.74 & $-16 \%$ \\
\hline $\begin{array}{l}\text { Men } \\
1-50 \text { units } \\
51 \text { or more }\end{array}$ & $\begin{array}{r}295 \\
34\end{array}$ & $\begin{array}{l}0.77 \\
3.53\end{array}$ & $\begin{array}{l}0 \cdot 74 \\
2 \cdot 24\end{array}$ & $\begin{array}{r}-3 \% \\
-37 \%\end{array}$ \\
\hline $\begin{array}{l}\text { Women } \\
1-10 \text { units } \\
11 \text { or more }\end{array}$ & $\begin{array}{r}105 \\
29\end{array}$ & $\begin{array}{l}0 \cdot 30 \\
1 \cdot 10\end{array}$ & $\begin{array}{l}0.28 \\
0.66\end{array}$ & $\begin{array}{r}-6 \% \\
-41 \%\end{array}$ \\
\hline
\end{tabular}

women drinking more and less than 10 units a week. Moreover, although the low adverse effects scores of moderate drinkers were only slightly reduced in 1981-2 the high scores of the heavy drinkers were reduced considerably, by $37^{\circ}$ in men drinking over 50 units a week ( $t=5.25$ and $\mathrm{p}<0.001)$ and by $41 \%$ in women drinking more than 10 units a week $(p=0.53)$. So the heaviest drinkers were not only drinking less in 1981-2, they were also suffering considerably fewer adverse effects.

Three of the questions on adverse effects (those concerning drinking first thing in the morning, morning shakes, and remaining intoxicated for days on end) were intended to detect people who were, or were becoming, physically dependent on alcohol. The response to the 1981 price rise of the 36 men and six women who answered yes to one or more of these questions in 1978-9 is of particular interest in view of the widespread assumption that dependent drinkers are unaffected by financial considerations. In fact, their average consumption fell from 37.8 units in 1978-9 to 30.4 units in 1981-2 and their average adverse effects score from 4.05 to $2 \cdot 74$, a $32 \%$ reduction, which is statistically significant $(t=3.46$ and $\mathrm{p}<0.01)$.

\section{Discussion}

The central finding of this before and after survey is that a representative population of 463 regular drinkers in the Lothian region reduced their alcohol consumption by $18 \%$ between 1978-9 and 1981-2 and simultaneously experienced a $16 \%$ reduction in adverse effects. The main cause of this fall in consumption was probably the rising cost of alcoholic beverages relative to the cost of living and average incomes during that three year period. This was certainly the opinion of the respondents themselves, and the fact that consumption of beer was reduced more than that of other alcoholic beverages, and that those who reduced their consumption did so mainly in 1981, supports this view. This $18 \%$ reduction is, however, an overestimate of the overall reduction in consumption in the region. This is because none of the 233 occasional drinkers from the 1978-9 survey was reinterviewed, so that any alcohol they happened to consume during the 1981-2 survey week was not included. In fact, in the United Kingdom as a whole per capita consumption of beer fell by $11 \%$ and of spirits by $17 \%$ between fiscal years $1978-9$ and $1981-2 .{ }^{10}$

The effect of economic recession was largely restricted to its effect on unemployment rates. As table I shows, average earnings in the Lothian region and average personal disposable income in Scotland both rose by more than the cost of living between the two surveys, suggesting that those who kept their jobs were slightly better off at the time of the second survey. Rising unemployment was, however, responsible for part of the fall in consumption and of the associated reduction in adverse effects. We recalculated the changes in consumption and adverse effects in our 463 respondents after excluding the 32 men and five women who had been unemployed in either 1978-9 or 1981-2. This showed that these 37 people- $8 \%$ of the populationwere responsible for $20 \%$ of the overall fall in consumption, and $25 \%$ of the fall in men, and for $27 \%$ of the overall reduction in adverse effects, and $33 \%$ of the reduction in men. These percentages give a somewhat inflated estimate of the effects of rising unemployment per se, because the drinking habits of these men and women would have been influenced by the rising price of alcohol as well as by the direct economic and social effects of unemployment, but they do serve to indicate the maximum effect attributable to rising unemployment. Eliminating these 37 unemployed men and women reduces the mean reduction in the adverse effects score of the remaining 426 from $0 \cdot 145$ to $0 \cdot 115$. As a result the reduction no longer quite reaches the $5 \%$ significance level $(t=1.89, \mathrm{p}<0.06)$ but the reduction in the mean adverse effects score of men drinking over 50 units in 1978-9 remains highly significant $(t=2 \cdot 84$, $\mathrm{p}<0.01)$.

The main reason for conducting this survey was to find out to what extent heavy drinkers and dependent drinkers reduced their alcohol consumption in response to a price rise. Although interpretation of the changes in consumption taking place between the 1978-9 and 1981-2 surveys was complicated by a regression to the mean effect, by the fact that we were unable to reinterview the 233 occasional drinkers from the first survey, and by simultaneously rising unemployment, the results indicate that heavy drinkers-men drinking more than 50 alcohol units a week and women drinking over 10 units a weekreduced their consumption at least as much as light or moderate drinkers. More important still, they suffered considerably fewer adverse effects as a result. Furthermore, the 42 subjects whose adverse effects responses suggested that they were, or were becoming, dependent also reduced their consumption and suffered significantly fewer adverse effects. The findings of this study indicate, therefore, that an increase in the excise duty on alcoholic beverages can be an effective means of reducing the ill effects of excessive alcohol consumption, at least at a time when incomes are not rising faster than the cost of living.

We are grateful to Mr S Kendrick and Mr J C Duffy for statistical advice and computing help and to $\mathrm{Dr} T$ Myers for interviewing several elusive respondents.

\section{References}

1 Bruun K, Edwards G, Lumio M, et al. Alcohol control policies in public health perspective. Helsinki, Finnish Foundation for Alcohol Studies, 1975.

2 Kendell RE. Alcoholism: a medical or a political problem ? $\mathrm{Br}$ Med $\mathcal{f}$ $1979 ; \mathrm{i}: 367-71$

${ }^{3}$ Royal College of Psychiatrists. Alcohol and alcoholism. London, Tavistock Publications, 1979

4 World Health Organisation. Problems related to alcohol consumption. Technical report series 650. Geneva: WHO, 1980.

${ }^{5}$ Nielsen J. Delirium tremens in Copenhagen. Acta Psychiatr Scand, 1965; suppl 187.

${ }^{6}$ Department of Health and Social Security. Drinking sensibly. London: HMSO, 1981.

${ }^{7}$ Lees F. An argument for the legislative prohibition of the liquor traffic. London: Tweedie, 1857.

${ }^{8}$ Cook PJ. Alcohol taxes as a public health measure. In: Grant M, Plant M, Williams A, eds. Economics and alcohol. London: Croom Helm, 1983:190-6.

9 World Health Organisation. Community response to alcohol related problems. Phase I. Final report. Geneva: WHO, 1982.

10 The Brewers' Society. UK statistical handbook 1982. London: Brewing Publications Ltd, 1983.

Does a full stomach predispose to excessive mucus secretions from the bronchial tree-vagus mediated and thus cause coughing after a full meal?

I know of no gastric reflex stimulus to bronchial mucus secretion There are lung irritant receptors that respond to various stimuli, which may include substances absorbed from the gut, such as spices. Two other possible reasons for coughing after food are asthma provoked by food intolerance ("allergy") and gastro-oesophageal reflux with spill over into the trachea.-J BENNETT, consultant physician, Kingston upon Hull. 